\title{
Do We Need to Think More about Small Business Capital Budgeting?
}

\author{
Md. Mohan Uddin (Corresponding author) \\ School of Business \\ United International University \\ H-80, R-8/A, Dhanmondi, Dhaka 1209, Bangladesh \\ Tel: 88-017-1308-1780Ｅ-mail: mohanuddin@yahoo.com \\ Abu Zakir Md. Rasel Chowdhury \\ School of Business \\ United International University \\ H-80, R-8/A, Dhanmondi, Dhaka 1209, Bangladesh \\ Tel: 88-02-8821-466_E-mail: rase10608@yahoo.com
}

\begin{abstract}
Capital budgeting is one of the most important areas of finance literature. This paper discusses whether the capital budgeting theory of large business is well applicable for the small ones or not. If it is not, further development of theory becomes necessary. This paper conducted detail analysis of the reasons why the development is necessary. Followed by the analysis of some theoretical and empirical studies, this paper suggests specific factors to consider in future researches on capital budgeting theory for small businesses.
\end{abstract}

Keywords: Small business, Capital budgeting, Investment decision

\section{Introduction}

Capital budgeting is one of the most important areas of finance literature. The decision of capital budgeting, or the allocation of fund in assets for a long term, is obvious for both the large and small business. Existing theory of capital budgeting explains the investment decision-making pattern of large businesses very well. This paper discusses whether the capital budgeting theory of large business is well applicable for the small ones or not. If it is not, further development of theory becomes necessary. Followed by the analysis of some theoretical and empirical studies, this paper suggests specific factors to consider in future researches on capital budgeting theory for small businesses.

Understanding the pattern of capital budgeting in small businesses is important. Small business is a significant portion of total businesses in an economy. Also, small business constitutes the starting point for the entrepreneurs. According to Deek (1973), small business is an important asset within an advanced industrial economy. But they cannot make possible contribution for the economy if they are held back by managerial and entrepreneurial limitations. According to FitzRoy (1989), evidences are there to support that small firms are more innovative. Furthermore, it is observed that the overall demand for customized goods and services increase than the increase of mass-produced goods (Carlsson, 1989). Thus, worldwide experience shows that equitable development from economic and social context is enhanced by the contribution of small businesses (Jeppesen, 2005). All these studies indicate that successful small business is important for an economy. And, the success of small business depends on optimal capital budgeting decision. This is why small business capital budgeting demands special attention for complete theoretical development.

This paper is organized in six sections. Fixing up the definition of small business is important and the analysis on it is in the second section. The third section analyzes the theoretical evidence to show how the small business capital budgeting has a different decision-making environment. Empirical evidences are discussed in section four. Section five and six describes the findings, and conclusion plus research implications respectively.

\section{Definition of small business}

Small is a relative term. Whether the size of a business is small or large, is a very difficult question. The purpose of the definition can play role in determining the borderline. Most of the studies on small business capital budgeting used 
either number of employees or amount of sales revenues as the attribute to create a line between large firms and small firms. Grablowsky and Burns (1980) and Graham and Harvey (2001) defined small business based on revenue, which is less than $\$ 5$ million and \$1 billion respectively. Danielson and Scott (2006) used number of employee as the differentiating factor. They used the benchmark of 250 employees to define small business. Stanley (1997) used both the number of employee and sales revenue, which are fewer than 1000 employees and less than $\$ 5$ million revenue. Pattillo's (1981) was exceptional where the small and large are differentiated based on their size of capital investment. However, the differences in the definitions of small business indicate the necessity of developing an appropriate definition that would be useful for this kind of research. Here, Deek's (1973) statement may help as a guideline to determine an acceptable borderline between small and the large: "Small firms are owner-managed. In the small firm the work of the owner is concerned primarily with management or superintendence."

\section{Capital budgeting in small and large business}

The theory of capital budgeting supports Net Present Value (NPV) method most, which involves discounting all relevant cash flows at a market determined discount rate such as the cost of capital. Determination of cost of capital requires the separation principle that requires that the investment decision can be made independent of shareholders' (owners') tastes and preferences. Since the ownership is not readily marketable, separation principle, and thus the market-determined discount rate are inappropriate for closely held and small businesses (McInish and Kudla, 1981). Therefore, there is some degree of complexity and inappropriateness employing existing capital budgeting theory for small business investment decisions.

In case of small businesses, the owner will have to make decisions concerning production, sales, finance and administration without any specialist management support or advice (Deek, 1973), which is not the same at all for large incorporated firms. Danielson and Scott (2007) have worked on the agency problem in small firm investments. Their result shows that agency conflicts affect a firm's investment decisions in different ways before and after the separation of ownership and control.

Therefore, there is a need to address the problem of decision-making in small business, and some scholars have been working in this field. For example, McMahon and Stanger (1995) suggest that small business financial objective function is sympathetic to existing financial thought, but capture complexities arising in small business. They also argue that the small business financial objective function should reflect the kinds of enterprise-specific risk that typically exist in small businesses arising from liquidity, diversification, transferability, flexibility, control, and accountability considerations.

In other words, the capital budgeting process of small business is likely to be different from that of a large business. The size and availability of capital, investment opportunities, and the nature of the decision makers being different for small businesses may partially explain this difference.

\section{Some evidences}

Several researchers have conducted the study of capital budgeting decision-making pattern of small businesses but the number is lower than what is for large incorporated businesses. For example, all of Grablowsky and Burns (1980), Pattillo (1981), Block (1997), Graham and Harvey (2001), and Danielson and Scott (2006) have conducted studies to find the pattern of capital budgeting decisions of small businesses. Although, their sample size was much different from one study to another, their location of research, data, and methodology were almost same (shown inTable 1).

All of these studies used survey methodology. Sample size varied from 65 to 792. Pattillo's (1981) study was unique among these in terms of sample size and data. This study also compared national and multinational firms in USA. In addition to survey data, this study used substantial amount of other data from the operation manuals and specific case studies of the firms in the small sample. Additionally, the chief financial officer of each firms were interviewed very deeply. Therefore, the small number of firms in the sample is justified by in depth analysis of their decision-making process.

In Grablowsky and Burns (1980) study, lack of understanding as well as expertise of the concepts of capital budgeting are the reason behind small businesses less use of modern capital budgeting techniques. Observing that the smaller firms used single techniques, such as, inspection, 'need', or payback for evaluating capital investment proposals, Pattillo (1981) states "Findings of variances from the theory by the sample firms could be useful in determining theoretical gaps and could indicate the most useful future orientation of new techniques or refinements in theory or technique." The findings of these studies are given in the following table. Graham and Harvey (2001) and Block (1997) found more use of payback period method than discounted cash flow methods in small firms. Danielson and Scott (2006) found that investment decision of small and large firms differ and many small businesses do not use sophisticated capital budgeting techniques or do not involve discounted cash flow methods. They rely on gut feel or easy techniques like payback period. They showed that the lack of financial sophistication, assumptions of capital budgeting theory being not true for small firms, size, short operating history, lack of education of the top decision maker, lack of 
discretion in investment decision, credit constraints, difficulties in quantifying future cash flow are the possible reason why small firms decide differently in capital budgeting. These results are given in table 2.

\section{Findings}

We have found that there is no well accepted standard definition of small business in the literature that can be used to create the basis of applying the theory of capital budgeting. Still, it is possible to say that the theory of capital budgeting, which is constructed under assumptions related to large incorporated businesses, is not fully applicable for small businesses. NPV is the ultimately suggested method of capital budgeting that involves estimation of cash flows, and the market determined discount rate. Both of these two tasks require expertise and relevant knowledge. Decision-makers in small businesses may lack this knowledge or may find it cost ineffective to hire that kind of expertise. Moreover, market determined discount rate is not possible to find since the market for small business's capital is not liquid, which does not allow thinking about separation of investment and financing decision. Also, the effect of agency conflict, when it is present, on the investment decision, is different for small businesses because of lack of separating ownership and control. Size and availability of capital as well as investment opportunities are also among some other factors contributing to this conclusion.

Some empirical studies done so far have found results demonstrating the inapplicability of modern capital budgeting theory for small businesses. In addition to above, some other reasons found from these empirical studies are, lack of knowledge, cost of hiring outside consultant, low priority of planning, size and availability of capital, size and availability of investment opportunities, tendency of high reliance on gut feel or easy techniques like payback period, short operating history, credit constraints, difficulties in quantifying future cash flow, and limited discretionary alternatives for investments.

\section{Future research and conclusion}

We suggest more development in the theory of capital budgeting in order to integrate the different scenario of small businesses. This study suggests some specific area of development: first, what the definition of small business should be to work on the new development of the theory, second, how the discount rate determination for small businesses should be addressed, and finally, how all other factors of difference to incorporate in the small businesses capital budgeting theory. In fact, it is necessary to test the same decision making pattern in non-US economies, since almost all the studies are US-based. This extension of study would help to understand any additional factor due to difference in development among other economies.

Although small business seems 'small', collectively it is huge and significant for an economy. Many countries are becoming much more serious about developing the small business sector. Understanding the pattern of their investment decision would help to complete the theory of capital budgeting. This, again, may have significant policy implications for the small business development sector.

\section{References}

Block, S. (1997). Capital budgeting techniques used by small business firms in the 1990s. The Engineering Economist, Vol. 42, No. 4, 289-302.

Carlsson, B. (1989). The evolution manufacturing technology and its impact on industrial structure: an international study. Small Business Economics, (1): 21-37.

Danielson, M. G. \& Scott, J. A. (2006). The capital budgeting decisions of small businesses. Journal of Applied Finance, (Fall/Winter) 45-56.

Danielson, M. G. \& Scott, J. A. (2007). A note on agency conflicts and the small firm investment decision. Journal of Small Business Management, 45(1) 157-175.

Deeks, J. (1973). The small firm - ssset or liability? The Journal of Management Studies, (February) 25 -47.

FitzRoy, F. R. (1989). Firm size, efficiency and employment: a review article. Small Business Economics, (1):75-80.

Grablowsky, B. J. \& Burns, W. L. (1980). The application of capital allocation techniques by small business. Journal of Small Business Management, Vol. 18, No. 3, (June) 50-58.

Graham, J. \& Harvey, C. (2001). The theory and practice of Corporate Finance: evidence from the field. Journal of Financial Economics, 60 (Nos. 2-3, May), 187-243.

Jeppesen, S. (2005). Enhancing competitiveness and securing equitable development: can small, micro, and medium-sized enterprises (SMEs) do the trick? Development in Practice, Vol. 15, No. 3 \& 4, June. 463-474.

McInish, T. H., \& Kudla, R. J. (1981). A new approach to capital budgeting in closely-held firms and small firms. American Journal of Small Business, Vol. 5, No. 4, 30-35.

McMahon, R. G. P. \& Stanger, A. M. J. (1995). Understanding the small enterprise financial objective function. entrepreneurship theory and practice, (Summer), 21-39. 
Pattillo, D. M. (1981). Capital investment practices of small manufacturers: American versus multinational. Journal of Small Business Management, (April) 29-36.

Stanley, B. (1997). Capital budgeting techniques used by small business firms in the 1990s. The Engineering Economist, Vol. 42, (Nos. 4, Summer) 289-302.

Table 1. Details of the empirical studies on small business capital budgeting

\begin{tabular}{|c|c|c|c|c|}
\hline Resear-cher(s) & Title of the Research & $\begin{array}{l}\text { Location of } \\
\text { Research }\end{array}$ & Sample Size & Data and Methodology \\
\hline $\begin{array}{l}\text { Grablowsky } \\
\text { and Burns } \\
\text { (1980) }\end{array}$ & $\begin{array}{l}\text { The Application of Capital } \\
\text { Allocation Techniques by } \\
\text { Small Business }\end{array}$ & USA & 65 & $\begin{array}{c}\text { Data: Survey of small } \\
\text { businesses } \\
\text { Tools for analysis: only basic } \\
\text { statistical tools }\end{array}$ \\
\hline $\begin{array}{l}\text { Pattillo } \\
\text { (1981) }\end{array}$ & $\begin{array}{l}\text { Capital Investment Practices } \\
\text { of Small Manufacturers: } \\
\text { American versus Multinational }\end{array}$ & $\begin{array}{l}\text { USA and UK } \\
\text { based } \\
\text { multinationals } \\
\text { in USA }\end{array}$ & $\begin{array}{l}8 \text { firms, } 4 \mathrm{Us} \\
\text { and , } 4 \\
\text { UK-owned } \\
\text { multinational }\end{array}$ & $\begin{array}{l}\text { Data: Survey of CFOs of } \\
\text { small businesses, Operating } \\
\text { manuals and specific case } \\
\text { studies from the firms were } \\
\text { obtained where available } \\
\text { Tools for analysis: paired } \\
\text { comparison method }\end{array}$ \\
\hline $\begin{array}{l}\text { Block } \\
(1997)\end{array}$ & $\begin{array}{l}\text { Capital Budgeting Techniques } \\
\text { Used by Small Business Firms } \\
\text { in the } 1990 \mathrm{~s}\end{array}$ & USA & 232 & $\begin{array}{c}\text { Data: Survey of small } \\
\text { businesses } \\
\text { Tools for analysis: only basic } \\
\text { statistical tools }\end{array}$ \\
\hline $\begin{array}{c}\text { Graham and } \\
\text { Harvey } \\
(2001)\end{array}$ & $\begin{array}{l}\text { The Theory and Practice of } \\
\text { Corporate Finance: Evidence } \\
\text { from the Field }\end{array}$ & $\begin{array}{l}\text { USA and } \\
\text { Canada }\end{array}$ & 392 & $\begin{array}{l}\text { Data: Survey of CFOs in small } \\
\text { and large businesses } \\
\text { Tools for analysis: correlation, } \\
\text { univariate analysis, robustness } \\
\text { check, etc }\end{array}$ \\
\hline $\begin{array}{l}\text { Danielsn and } \\
\text { Scott } \\
(2006)\end{array}$ & $\begin{array}{l}\text { The Capital Budgeting } \\
\text { Decisions of } \\
\text { Small Businesses }\end{array}$ & USA & 792 & $\begin{array}{l}\text { Data: Survey of small } \\
\text { businesses } \\
\text { Tools for analysis: Binomial } \\
\text { Z-score, multinomial logit }\end{array}$ \\
\hline
\end{tabular}


Table 2. Findings of the empirical studies on small business capital budgeting

\begin{tabular}{|c|c|}
\hline Resea & Findings \\
\hline $\begin{array}{l}\text { Grablowsky and } \\
\text { Burns } \\
\text { (1980) }\end{array}$ & $\begin{array}{l}\text { a) There were only three firms in the total sample, which used advanced budgeting techniques, } \\
\text { and only one indicated that these were used to the fullest extent. } \\
\text { b) The main reasons are probably management's lack of understanding of these techniques and the } \\
\text { costs associated with hiring an outside consultant who is familiar with them. Additional reasons } \\
\text { include a lack of the knowledge and staff needed to properly analyze investment opportunities. } \\
\text { c) Planning, however, tends to be an activity from which the small businessman can see no } \\
\text { obvious or direct effect on his profits; therefore, it is often given a low priority. } \\
\text { d) Careful planning would also make the data needed for capital management techniques more } \\
\text { readily available; and, with management's increased understanding, the cost of employing } \\
\text { capital management techniques would decrease, resulting in a more efficient and competitive } \\
\text { business climate. }\end{array}$ \\
\hline $\begin{array}{l}\text { Pattillo } \\
(1981)\end{array}$ & $\begin{array}{l}\text { a) Support for the linkage of differences in capital investment practices among firms with the } \\
\text { ownership nationality variable. } \\
\text { b) The larger firms in the sample were found to possess formal capital budgets. This difference, } \\
\text { however, was felt to be a function of the greater level of capital expenditures in the larger firms. }\end{array}$ \\
\hline $\begin{array}{l}\text { Block } \\
(1997)\end{array}$ & $\begin{array}{l}\text { a) Payback method is still the preferred approach by } 42.7 \text { percent of the firms. } \\
\text { b) Increased use of discounted cash flow methods than that in similar surveys at that time }\end{array}$ \\
\hline $\begin{array}{l}\text { Graham and } \\
\text { Harvey } \\
(2001)\end{array}$ & $\begin{array}{l}\text { a) Large firms rely heavily on present value techniques and the capital asset pricing model, while } \\
\text { small firms are relatively likely to use the payback criterion. }\end{array}$ \\
\hline $\begin{array}{l}\text { Danielson and } \\
\text { Scott } \\
(2006)\end{array}$ & $\begin{array}{l}\text { a) Investment decision of small and large firms might differ. Many small businesses do not use } \\
\text { sophisticated capital budgeting techniques or do not involve discounted cash flow methods. } \\
\text { They rely on gut feel or easy techniques like payback period. } \\
\text { b) They showed that the lack of financial sophistication, assumptions of capital budgeting theory } \\
\text { being not true for small firms, size, short operating history, lack of education of the top decision } \\
\text { maker, lack of discretion in investment decision, credit constraints, difficulties in quantifying } \\
\text { future cash flow are the possible reason why small firms decide differently in capital budgeting. }\end{array}$ \\
\hline
\end{tabular}

